\title{
Synovial Neoplasm
}

National Cancer Institute

\section{Source}

National Cancer Institute. Synovial Neoplasm. NCI Thesaurus. Code C8964.

A benign or malignant soft tissue neoplasm arising exclusively from the synovial

membrane. Examples include the diffuse giant cell tumor of tendon sheath, localized giant cell tumor of tendon sheath, and malignant giant cell tumor of tendon sheath. 